\title{
Exploring Novel Concept of Agni and its Clinical Relevance
}

\author{
Kajaria Divya*, Tripathi JS and Tiwari SK
}

Department of Kayachikitsa, IMS, BHU, Varanasi, India

\begin{abstract}
The torch of Ayurveda has remained burn brightly throughout the age's inspite of heavy winds of changes. Amidst a skeptical environment also it has maintained its towering position, due to its very own novel basics and dictums. The simple reason behind this truth is the strong basic fundamentals of Ayurvedic medical science that hold the domain of this life science. Ayurveda consider that no disease ever be develop without the derangement of Agni. Therefore in every disease Agni management gets the prime focus. Though in Ayurvedic literature, a detailed explanation of Agni is available but its practical application in the management of disease is lacking. The paper gives a comprehensive knowledge about the concept of Agni with clinical examples to illustrate its practical utility.
\end{abstract}

Keywords: Jathragni; Bhutagni; Dhatwagni

\section{Introduction}

Agni is the term given in Ayurveda for the whole process of energy liberation through digestion at the level of G.I.T and metabolism at the level of tissues. Digestion, metabolism and assimilation i.e. whole process of biological conversion and utilization of energy is symbolize by the term Agni. As we know that living beings are only able to utilize, conserve and transform the energy and this is the only process that makes them different from non-living, therefore being living and to maintain the living state depends upon the normalcy of the process of energy transformation. Once this process is interrupted it results in death and when it is malfunctioning it results in disease. Every second our body tries to maintain the homeostasis by balancing the energy input and energy output though various ongoing chemical processes, whatever we eat or drink is just adjuvant to this process. Even medicines have no more role than being energy stabilizers, being acting on receptors or as catalyst that either promote or inhibit a chemical reaction to maintain homeostasis. Ayurvedic concept of physiology, including biochemistry of digestion and metabolism, envisaged in Jatharagni, Dhatvagni and Bhutagni.

The manner in which the nutrition ingested is digested, the way in which its various components are metabolized into appropriate Dhatu or tissue element and how some of its constituents are broken down for being utilized for the production of energy required for vital activities, depends upon factors which are grouped under term Agni.

According to Ayurveda there are 13 types of Agni in body namely7 Dhatwagni, 5 Bhutagni and 1 Jathragni. Among these 13 Jathragni is the prime one and nourishes the other Agnis.

- Jathragni=refers to the whole process of digestion in G.I.T

- Bhutagni=refers to the final digestion in liver

AGNI

- Dhatwagni=refers to tissue metabolism

All the enzymes responsible for the process of digestion and metabolism are refers to Pitta. Thus Agni is the resultant and Pitta is the initiator or it can be said that Pitta is the cause and Agni is the result. In Ayurvedic texts these 13 types of Agni are further divided into four types on the basis of function as follows:

- Mandagni=Hyposecretion of digestive enzymes

- Triksnagni=Hypersecretion of digestive enzymes

- Vishmgni=Irregular secretion of digestive enzymes
- Samagni=Normal secretion of digestive enzymes Healthy state of Agni

\section{Functioning of Jathragni (Process of Digestion)}

\section{Jathragni works at 3 levels}

Madhuravasthapaka (production of Kapha/digestion of Carbohydrate)

Entrance of food in buccal cavity $\longrightarrow$ action of Bodhaka Kapha (one among three type of humor)

Total duration of Madhuravastha is 1 hour $\left\{\begin{array}{l}\mid \begin{array}{l}\text { Action of } \\ \text { salivary amylase } \\ \text { initiating } \\ \text { breakdown of } \\ \text { starch) }\end{array} \\ \text { Breakdown of } \\ \text { polysaccharides into } \\ \text { monosaccharides } \\ \downarrow \\ \text { Continue up to the } \\ \text { fundal part of stomach } \\ \text { Ends with the } \\ \text { production of Dhaturupi } \\ \text { Kapha } \\ \text { (Completion } \\ \text { of digestion of } \\ \text { carbohydrate) }\end{array}\right.$

*Corresponding author: Diyya Kajaria, Faculty of Ayurveda, Department of Kayachikitsa, IMS, BHU, Varanasi, India, Tel: 8808652724; E-mail: divyakajaria@gmail.com

Received September 25, 2013; Accepted October 22, 2013; Published October 24, 2013

Citation: Divya K, Tripathi JS, Tiwari SK (2013) Exploring Novel Concept of Agni and its Clinical Relevance. Altern Integ Med 2: 140. doi:10.4172/23275162.1000140

Copyright: $\odot 2013$ Divya K, et al. This is an open-access article distributed under the terms of the Creative Commons Attribution License, which permits unrestricted use, distribution, and reproduction in any medium, provided the original author and source are credited. 


\section{Amlavasthapaka (production of Pitta/digestion of proteins \& fats)}

Starts with the action of HCL secreted by parietal (oxyntic) cell on food

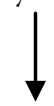

Acidic $\mathrm{pH}$ of stomach

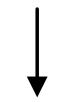

Activation of Pepsin \& Gastric lipase

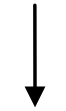

Cleavage of peptide bond by pepsin

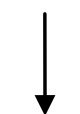

Digestion of protein \& production of acidified chyme

Acidified food from the stomach while passing through the duodenum

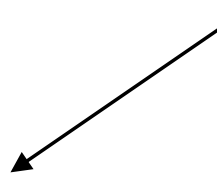

Leads to the secretion of

Aachcha pitta (bile) which in turn responsible for,

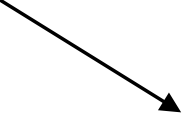

The secretion and discharge of

influencing tissue metabolism, especially

Achcha Pitta (bile) in this place

oxidative reactions and production of heat

This, aids in digestion of food in the intestines and the separation of the Sara (food nutrients) from the Kitta (stool)

Katuavasthapaka (Production of Vata/last stage of digestion added by action of colon bacteria, production of stool and residual gaseous)

The last stage of digestion in the colon occurs through the activity of bacteria. Numerous bacteria, esp. colon bacilli, are present normally in the absorbing colon i.e. cecum, ascending and transverse colon. These bacilli are capable of digesting small amount of cellulose, in this way providing a few calories of extra nutrition to the body. Bacteria are also involved in the digestion of protein into amino acid and amino acids into simpler substances like indole, sketole, hydrogen sulfide, and fatty acid. Other essential substances like vitamin K, Vitamin B12, thiamine, riboflavin are formed as a result of bacterial activity. The vitamin $\mathrm{K}$ is especially important because the amount of this vitamin in the daily ingested food is normally insufficient to maintain adequate blood coagulation. About $1500 \mathrm{ml}$ of chyme normally passes through the iliocecal valve into large intestine. The chyme remains in the large intestine for 3-10 hrs, it become solid or semisolid and contains nearly $100 \mathrm{ml}$ water. The sodium ions are absorbed by the mucosa of colon by active transport, creating an electrical potential gradient, which results in absorption of chloride ions. The absorption of sodium and chloride ions creates an osmotic gradient across the large intestinal mucosa, which in turn causes absorption of water.
These three phases are collectively known as Avasthapaka i.e. digestion at the level of G.I.T. Bhutagni work at the level of liver and known as Nisthapaka, whereas Dhatwagni works at the level of tissues.

\section{Clinical Assessment of Agni}

\section{Signs and symptoms of proper functioning of $\mathbf{A g n i}$}

- Adequate diet

- Timely evacuation of bowel and bladder

- Good strength

- Good resistance to infection (good immunity)

- Good Skin luster and texture

- Proper functioning of all sensory organ

- (Ca.Chi. 15/8-9)

\section{Mild/ moderate malfunctioning of Agni}

- Loss of appetite

- lethargy

- Recurrent infection

- Constipation/diarrhea

- Incomplete evacuation of bladder or difficult micturition

- Improper functioning of sense organs

- Depression/loss of feeling of happiness

\section{Severe malfunctioning of Agni}

- Collection of fluid in body (Ascitis, edema, pleural effusion, pericardial effusion etc.)

- Marked loss of energy and general debility

- Loss of enthusiasm

- Improper sleep, etc.

Malfunctioning of Agni leads to production of Ama (undigested foods that remains in tract and acts as antigens and are responsible for production of autoimmune diseases). Production of Ama may can occur at the level of Jathragni (improper digestion in G.I.T), Bhutagni (liver dysfunction) or Dhatwagni (disturbed tissue metabolism).

\section{Drug acting at the Level of Jathragni}

\section{Trikatu}

A polyherbal preparation having equal amount of three herbs namely Sunthi (Zingiber officianalis), Maricha (Piper nigrum) and Pippali (Piper longum) is supposed to work on Jathragni at the level of Madhuravasthapaka and Amalavasthapaka. They are believed to intensify salivary flow and gastric juice secretion, and help in digestion. Salivary and gastric secretions are increased when the nerve centers are stimulated by the sense of smell and by the presence of pungent principles in the foodstuff. Glatzel [1] while studying the effect of spices on the secretion and composition of saliva in humans observed that red pepper; ginger, capsicum, black pepper and mustard enhanced the secretion of saliva and the activity of salivary amylase. Further the saliva stimulating capacity was greatest for red pepper and mustard among these spices. Pai and Pathak [2] in their study with Indian foods 
reported a slightly increased acid secretion after food rich in spices, and a greater increase when spices were given along with pulses. Ginger (Zingiber officinale) is reported as best remedy for dyspepsia and indigestion; stomachic relieves stomach pain and nausea [3-5]. All the herbal as well as herbomineral preparations have carminative and digestive stimulant herbs.

\section{Drugs Acting at the Level of Bhutagni Bhringaraja (Eclipta alba)}

Bringaraja is one of the most potent herbs supposed to work at the level of Bhutagni. It is one of the main ingredients of many drugs use for the management of hepatitis and other liver disorder. It contains resin, alkaloid (eclipticine), and Wedelolactone (C15H10O7). Another alkaloid, 25-ß-hydroxyverazine has been reported from alcoholic extract of the Eclipta alba. Saxena et al. [6] studied the hepatoprotective effect of ethanol/ water (1:1) extract of Eclipta alba in rats against carbon tetrachloride induced hepatotoxicity. The researchers concluded that Eclipta alba prevented carbon tetrachloride induced hepatotoxicity by regulating the levels of hepatic microsomal drug metabolizing enzymes. Singh et al. [7] studied in vivo hepatoprotective activity of active fractions from ethanolic extract of Eclipta alba leaves. The extract was further fractionized and agent with potent hepatoprotecvtive activity was looked for. One fraction was containing wedelolactone and other fraction was containing apigenin, 4-hydroxybenzoic acid and protocatcheuic acid. The second fraction was found to be more active hepatoprotective. Dixit and Achar [8] studied the hepatoprotective activity of Eclipta alba in guinea pigs against carbon tetrachloride induced hepatotoxicity. It was concluded that Eclipta alba has significant hepatoprotective activity against carbon tetrachloride induced hepatotoxicity.

\section{Picrorhiza kurroa (Kutaki)}

According to Ayurveda Kutai (Picrorhiza kurroa) act as Pitta rechaka i.e. it helps in expulsion of bile. Modern clinical studies have confirmed the efficacy and safety of Picrorhiza kurroa for the treatment of liver disease. The chemistry of Picrorhiza kurroa is complex. The active constituent is known as kutkin, a mixture of kutkoside and picroside. Pharmacologically, Kutkin (Picrosides and kutkosides) has hepatoproptective activity. Apocynin is a potent NADPH oxidase inhibitor and has anti-oxidant and anti-inflammatory activity. Kutaki is the main ingredient of herbomineral preparation Arogyavardhini that is use most frequently for the management of liver disorder. According to Ayurveda, Arogyavardhini is supposed to work on Bhutagni level therefore its use is not restricted up to only liver disorders rather it can be use in all type of ailment related to chronic gastrointestinal disorders/digestive diseases.

\section{Cucurma longa}

Curcuma longa commonly known as turmeric is another plant which has got scientists attention as novel hepatoprotective agent. Dried rhizomes are used in medicine. It is cultivated throughout India. It is supposed to work on Bhutagni and therefore helpful in ailment results due to Bhutagnimandya like Prameha (Diabetes Mellitus), Kamala (Hepatitis) etc.

\section{Andrographis paniculata}

Andrographis paniculata is well known medicinal plant for its usefulness in liver diseases. In Ayurveda it is known as Bhunimba or Kalmegha. It is used as bitter tonic and febrifuge. Because of bitter taste it is popularly known king of bitters. It contains diterpene lactones (Andrographolide, neoandrographolide and kalmeghin). Shukla et al. [9], studied the cholretic activity of Androgrpaholide. The diterpene lactone produced dose dependent chloretic effect evidenced by increase in bile flow, bile salt and bile acids in animal models. The cholretic effect of Andrographis paniculata was found to be better than silymarin. According to Trivedi and Rawal [10], alcoholic extract of Andrographis paniculata demonstrated significant hepatoprotective activity against carbon tetrachloride induced hepatotoxicity. The fact was further supported at morphological, biochemical and functional parameters.

\section{Drug Acting on Dhatwagni [11,12]}

- Rasagni-Khajoora (Phoenix dactylifera), Munakka (Ribes nigrum), Nagarmotha (Cyperus rotandus), etc.

- Raktagni-Manjjistha (Rubia Cordifolia), Sariva (Hemidesmus indicus), Khadira (Acacia catechu), Mandoora (Incinerated iron oxide), Kasisa (Ferrous sulphate), etc.

- Mamsagni- Guggulu (Commiphora Mukul), Kshara, Eranda (Ricinus communis), etc.

- Medagni-Kanchanara (Bauhinia variegate), Guggulu (Commiphora Mukul), Triphala, Louhabhasma, Agnimantha (Premna integrifolia), etc.

- Asthyagni-Laksha (Laccifer Lacca), Asthishrinkhala (Cissus quadrangularis), Nagabala (Sida veronicaefolia Lam), Godanti, Muktapisti, Shallaki (Boswellia serrata), etc.

- Majjagni-Guduchi (Tinospora cordifolia), Aswagandha (Withania somnifera), Rajatabharma, etc.

- Sukragni-Kapikacchu (Mucuna pruriens), Vidarikanda (Ipomoea Digitata), Satavari (Asparagus racemosus), Mash (Vigna mungo), etc.

\section{Clinical Illustration of Malfunctioning of Agni}

\section{Case-I}

A male patient of age 32 year, presented with the $\mathrm{C} / \mathrm{O}$ low backache with marked stiffness, which was more marked at early morning for last 2 years. O/E, tenderness over lumbosacral area was present, no spinal deformity was observed, pain on sacroiliac compression, and restriction of movements of lumbar spine in all direction was observed. The patient was diagnosed as having Ankylosing spondylitis on the basis of laboratory investigation and imaging techniques. According to Ayurveda there is malfunctioning of Jathragni leading to diminution of subsequent Agni. Malfunctioning of Agni causes production of Ama (HLA-B27 antigen is the clinical marker for the presence of Ama).

\section{Management given}

- Vrihatavatachintamani rasa-250 mg divided in two doses and given with water $\mathrm{E} / \mathrm{S}$

\section{- Vataghani Vati-2 tab TDS with lukewarm water}

(Ingredient: decoction of Nyctanthes arbor-tristis leaves)

*(Note: The management is only for early stage of disease when there is mild rediculopathy and the disease manifests only in lower limbs)

As the disease progress, the spine becomes more ankylosed, spinal rigidity and secondary osteoporosis occurs causing Spinal 
Canal Stenosis. When there is significant nerve compression either due to osteophytes or due to malignancy causing pseudoclaudication (discomfort in legs), marked restriction of spinal movement following management can be given:

$\left.\begin{array}{l}\text { Vrihatavatachintamani rasa-125 mg } \\ \text { Tamra bhasma-40 mg } \\ \text { Sahastraputi abhraka-150 mg } \\ \text { Vanga bhasma-150 mg }\end{array}\right\} \begin{aligned} & \text { Divided into two doses } \\ & \text { and given with madhu }\end{aligned}$

$\left.\begin{array}{l}\begin{array}{l}\text { Dashmula Kwatha-50 ml } \\ \text { Punarnava mandoora-500 mg } \\ \text { Yavakshara-500 mg }\end{array} \\ \text { Tase-II }\end{array}\right\}$ Twice in a day

\section{Case-II}

A 56 year old male patient presented with altered sensorium, Rt side hemiplegia, loss of speech for $6 \mathrm{hrs}$. O/E, patient was semiconscious, he was hypertensive but neither there was any valvular heart disease present nor there was presence of any bruits over carotids. He was found to be suffering from UMN paralysis of Rt upper and lower limbs including the paralysis of lower half of the Rt face (i.e UMN type of facial paralysis in the right) i.e. Rt sided complete hemiplegia. There was clasp-knife type spasticity, loss of superficial reflexes, brisk tendon reflexes and presence of extensor plantar response.

\section{Management given}

$\left.\begin{array}{l}\text { - Vatakulantaka rasa-5 g } \\ \text { Vaca churna-10 g } \\ \text { Aswagandha rasayana-100 g }\end{array}\right\} 1$ TSF - B.D with lukewarm milk

*(Note: Vaca churna-250 mg divided in two doses with madhu is also very effective in epilepsy. Seed (8-10/daily) of white pumpkin is also very effective in seizures.)

Clinical use of following combination given in CVA with Aphasia showed highly significant improvement in symptoms:

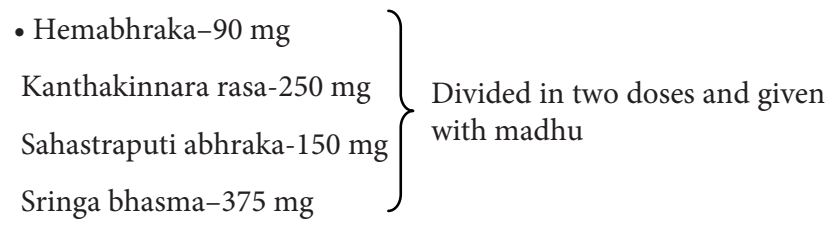

As there is Avarana followed by Dhatukshaya (depletion of tissues) in case of CVA, appropriate Rasayana (rejuvenation) therapy should be adopted according to Prakriti (biophysioconstituent of individual) of patient. For example Guduci Swarasa (Tinospora cordifolia), Amalaki rasayana (Phyllanthus emblica L.), Aswagandha rasayana (Withania somnifera) can be given.

Mada (delirium), Murccha (syncope) and Samyasa (coma) are Rakta Pradosaja Roga (blood disorders). As there is depletion of Rakta dhatu (loss of blood) in case of CVA, Rakta Prasadaka (blood purification treatment) and Raktavivandhahara (blood thinner treatment) chikitsa is best. Guduci (Tinospora cordifolia) is the best herb that can use for both this purpose.

\section{Case- III}

A female patient of age 46 year had presented with $\mathrm{C} / \mathrm{O}$, vomiting 4-5 times/day, loss of appetite, excessive gas formation, loss of body weight and excessive weakness, $\mathrm{O} / \mathrm{E}$, pallor + , icterus + , oedema $+(\mathrm{B} / \mathrm{L}$ pedal oedem), cyanosis - ve, clubbing -ve.

P/A: Non tender hepatomegaly present. Patient was diagnosed as case of CA G.B.

\section{Management given:}

- Vaikranta (as a substitute of Hiraka)-250 mg

Tamrasindura-200 mg

Sahastraputi abhraka-150 mg

Vanga bhasma-125 mg

Kashisa bhasma-250 mg

Manikya bhasma-200 mg

- C-Kshaya (Kwatha)-50 ml-B.D.

- Tab AS 3-2 tabs T.D.S with lukewarm water.

$\checkmark$ Ingredient of C-Kashaya-Shirisha chala (bark of Albizzia lebbeck), Tulsi (Ocimum sanctum), Nimba gatha (nodular growth of Azadirachta indica) etc.

$\checkmark$ Attaching chemotherapy drugs to small particles called nanodiamonds can make the drugs more effective. (Science Transitional Medicine).

$\checkmark$ Anticancer drugs tend to become ineffective because cancer cells quickly pump them out before they have had time to do their work. Nanodiamonds overcome this problem because the cellular transport proteins that usually pump the drug out of the cell can't carry them.

$\checkmark$ Shirisha (Albizzia lebbeck) is said to be Vishaghna (anti-toxin). According to Ayurveda every disease roots from Annavisha which should be treated first.

$\checkmark$ The logic behind using Nimba gatha (nodular growth of bark) is "Purusha loka Samya Sidhanta". According to this principle the law governing biological system and universe is same.

$\checkmark$ Kasisa acts on Raktagata ama and is effective in Raktadhatu Kshayajanya Pandu (iron deficiency anemia).

\section{Case-IV}

A female patient of age 45 year, presented with the $\mathrm{C} / \mathrm{O}$ itching and maculo-papular eruptions all over body for 10 years. O/E, the lesions were red with dry silvery white scaling. Lesions were present over scalp also. Nail deformity namely onycholysis and subungal hyperkeratosis was also found. The patient was diagnosed as Psoriasis on the basis of clinical features.

\section{Management given}

- Triphala churna - 3 g B.D with luke warm water

- Gandhaka rasayana-20 g

Amalaki rasayana-100 g

1 TSF B.D with milk

Haridrakhanda-100 g

- Pancatikta ghrita guggulu-2 tab TDS with lukewarm water 
In condition of Galata Kustha (Suppurated lesion) following management can be given:

$$
\left.\begin{array}{l}
\text { - Rasamanikya- } 50 \mathrm{mg} \\
\text { Gandhaka rasyana-1 g } \\
\text { Pravala pisti- } 375 \mathrm{mg}
\end{array}\right\} \quad \text { divided in two doses with madhu }
$$

Avagaha (tub bath): The following herbs use for cleansing skin lesions shows significant result:

Karanja (Pongamia pinnata), Nimba (Azadirachta indica), Saptaparna (Alstonia scholaris), Tulsi (Ocimum tenuiflorum), Shirisha (Albizzia lebbeck), Apamarga (Achyranthes aspera) and Nirgundi (Vitex negundo).

Amalatas (Cassia fistula): It is a herb that can be successfully used singly for the management of skin disorders. Paste of Amaltaspatra (paste of Cassia fistula leaves) mixed with Kanji should be applied over affected area for $30 \mathrm{mins}$ and then wash with lukewarm water.

\section{Discussion}

The whole empire of Ayurveda is based on the concept of Agni. Kayachikitsa (internal medicine) being the synonym of Agni emphasize the importance of this concept in the management of diseases. Basically whole of the treatment methodology in Ayurveda revolves around the modulation and management of Agni. Agni literally means fire and in human being it denotes the power of digestion, metabolism and assimilation. Derangement of Agni produces diseases and its destruction causes death. Derangement of Agni leads to production of AMA. Ama is said to be the root cause of all diseases. Uprooting the cause is the main aim of treatment. With the advancement of science everything changes, more polluted air to breathe, more adulterated food to eat and more toxic water to drink. What more we require to live a healthy life? We are evidenced that the world is threatened not by communicable diseases rather by non-communicable diseases. Alarming increase in obesity, cardiac diseases, diabetes all are outcome of deranged metabolism and comprises the syndrome of metabolic diseases. Now a day there is paradigm shift in the outlook for the management of such diseases from curative to conservative one. Now modern medical science also advocates dietary and life style management for the restoration of health. In such circumstances, the basic laws of Ayurveda may give the new direction in planning the management strategy for such diseases. The whole internal medicine in Ayurveda is based on the treatment of Agni. Ayurveda accept that Agni is present in every paramanu or cell of the body and not only in digestion and metabolism but every transformation in the body takes place essentially with Agni as the energy required to do so. Therefore, when we consider "Agni" in the body, we must not restrict ourselves to Jathragni as it commonly means, but as a comprehensive view, we have to think of Agni as a principle, present in each and every cell of the Panchahuthika body. When Agni is in balanced state, maintains healthy condition of the body any derangement in the normal function of "Agni" in the body will affect the transformations taking place in the body. Thus, Mandagni will result in the formation of waste/indigested products, which are the intermediate stages of a total change, because here Agni is locking in the capacity to transformation them in end products. Such intermediately products formed in the body may be comprehensively called as Ama. As Agni is present in each and every cell of the body, accordingly Ama formed by derangement of Agni is also present in each and every cell. It will also be of several types. In most of the disease some types of Agnimandya is often found. Therefore understanding the concept of Agni and its practical applicability is very essential for an Ayurvedic Physician as well as Ayurvedic Scholar. In clinical practice we use broad term i.e. Agni rather than Pitta to evaluate/assess the effect of drug on body. Status of Agni in the body can be evaluated on the basis of specific signs \& symptoms. In Ayurveda polyherbal drugs are mainly use for the management of diseases. In the light of science we today know that polyherbal compounds consists of multiple phytoconstituents targeted to multiple molecules in the body. In synthetic drugs it is always known that a particular metabolite is targeted to a particular protein/enzyme/receptor etc, but in polyherbal compound where several phyto-constituents are working simultaneously on different targets (e.g.-signaling proteins, enzymes, receptors or even on genes) it is never be possible to evaluate the effect of drug on single parameter. In such case only overall effect of drug (i.e. whether drug is compatible to body or not) can be assess. Thus in Ayurveda Agni is used to assess the overall effect of drug on body.

\section{Conclusion}

Principles of Ayurveda which are interwoven with basic concept of life have significant value even in the life of modern men. Hence one cannot deny the implacability of these principles. The principles of Ayurveda are based on strict experimental studies of several years. These principles are the outcome of those studies. Several Acharyas have tested these principles for many years and then these principles have been given a place in Ayurvedic Samhita. But nowadays one is prone to do all those things which are harmful to his constitution, thereby increasing the incidence of his susceptibility to diseases. In such disease conditions, physicians have to use these principles for preventive and curative purpose.

\section{References}

1. Glatzel H (1967) Physiological aspects of flavour compounds. Bibl Nutr Dieta 9: 71-86.

2. Pai ML, Pathak JD (1956) Gastric response to Indian types of food. J Indian Med Assoc 27: 96-98.

3. Chopra RN, Chopra IC, Handa KL, Kapur LD (1958) Chopra's indigenous drugs of India. (2ndedn). Dhur \& Sons, Calcutta.

4. Warrier PK (1989) Spices in Ayurveda. Indian Spices 26: 11-5.

5. Chelladurai ASS (1991) Spices in Homeopathy medicines. Indian Spices 28 5-6

6. Saxena AK, Singh B, Anand KK (1993) Hepatoprotective effects of Eclipta alba on subcellular levels in rats. J Ethnopharmacol 40: 155-161.

7. Singh B, Saxena AK, Chandan BK, Agarwal SG, Anand KK (2001) In vivo hepatoprotective activity of active fraction from ethanolic extract of Eclipta alba leaves. Indian J Physiol Pharmacol 45: 435-441.

8. Dixit SP, Achar MP (1979) Bhringaraja in the treatment of infective hepatitis Curr Med Pract 23: 237-242.

9. Shukla B, Visen PK, Patnaik GK, Dhawan BN (1992) Choleretic effect of andrographolide in rats and guinea pigs. Planta Med 58: 146-149.

10. Trivedi NP, Rawal UM (2001) Hepatoprotective and antioxidant property of Andrographis paniculata (Nees) in $\mathrm{BHC}$ induced liver damage in mice. Indian J Exp Biol 39: 41-46.

11. Charaka Samhita with "Ayurvedeepika" commentary by Chakrapanidutta (2001), Varanasi.

12. Sushruta Samhita with "Ayurveda Tattva Sandipika" (1995) Kaviraj Ambikadutta Shastri part 1 and 2, Chaukhambha Sanskrit Sansthan, Varanasi. 